\title{
The Analysis of Environmental Degradation and Carica Agroforestry System as an Attempt of Environmental Restoration in Dieng Plateau
}

\author{
Aditya Pradana, Futuha Helen Sara, and Windarti Wahdaningrum
}

\begin{abstract}
The land of Dieng Plateau managed by the farmers in not sustainable way and now it's faced environmental problems, mainly erosion. This research aim to analyse the impact of potato farm that caused environmental degradation and the implementation of carica agroforestry in Dieng Plateau to reduce degradation. The method of this research is analysing qualitative and quantitative data from observation, interview, and literatures study. The result of this research proven that the rate of erosion can be reduced by the using of agroforestry, the erosion rate decrease from 463.86 tonnes/hectares/year to be 115.96 tonnes / hectares / year (estimation data by using USLE formula). The using of agroforestry had improved the people's welfare. Agroforestry brings more benefit than potatoes monoculture system. This project is very sustainable and will not make any compromising for the Dieng's future generation.
\end{abstract}

Index Terms-Dieng Plateau, potato farm, environmental degradation, carica agroforestry.

\section{INTRODUCTION}

Dieng Plateau is a post volcanic area that located between Wonosobo regency and Banjarnegara regency, in Central Java Province. Dieng located 2,000- 2,500 metres above sea level, with high annual precipitation rate about 2,270-4,835 $\mathrm{mm}$ /years. The topography is hilly-mountainous area with total area approximately 542.03 kilometres square. Dieng serves as the upstream catchment for its downstream, so provide substantial benefits to the ecology and social purposes. The range of annual temperature between $15-20^{\circ} \mathrm{C}$ at day and $10-5^{\circ} \mathrm{C}$ at night until early morning. These conditions provide very potential land for the growth of potato farming as Dieng's main commodity. [1]. The introduction of potato in Dieng began in 1970 s by the investor from Bandung city, then during green revolution in 1980s until 1990s the development of potato farm dominated almost all of Dieng's vegetable farmland. In that era the demand of market and the price of potato from is very high [2]. This condition led to changing the orientation of traditional farmer society into economic oriented farmer society. This phenomenon caused farmers do not pay attention to processing potato farm in the context of sustainability so this caused environmental degradation.

Dieng have approximately 17,000 inhabitants. Almost $77.36 \%$ the people work as a farmers. Their educational

Manuscript received November 25, 2014; revised January 9, 2015.

The authors are with the Environmental Geography Departement, Faculty of Geography, Gadjah Mada University, Indonesia (e-mail: adityawizard97@gmail.com,

wwahdanigrum@gmail.com). background also relatively low. In Batur District (Banjarnegara) $84.9 \%$ people finished their education in elementary school and in Kejajar District (Wonosobo) 89.6 $\%$ people finished their education in elementary school. Although most of them have relatively low educational background, they have relatively high income from potato field. The statistical data from Wonosobo Religion Agency, showed that most of participant for collective pilgrimage to Mecca come from Kejajar District in Wonosobo.

Year after year the potato crop productivity in Dieng began to decline. The statistical data from 1997 reported, that some vegetables commodities in Dieng Plateau showed a relatively low productivity, namely potato 16.6 tonnes/hectare, cabbage 22.1 tonnes/hectare, and carrots 8.8 tonnes/hectare. These problem occured due to environmental degradation in Dieng Plateau and nowadays become a major environmental issue in Wonosobo regency. The degradation caused by two main problems, due to deforestation and agricultural cultivation patterns that do not heed conservation techniques. Now, most of Dieng landscape is not covered by forest as can be seen in Fig. 1. Dieng nowadays look like a representation of the social, economic and ecological problems.

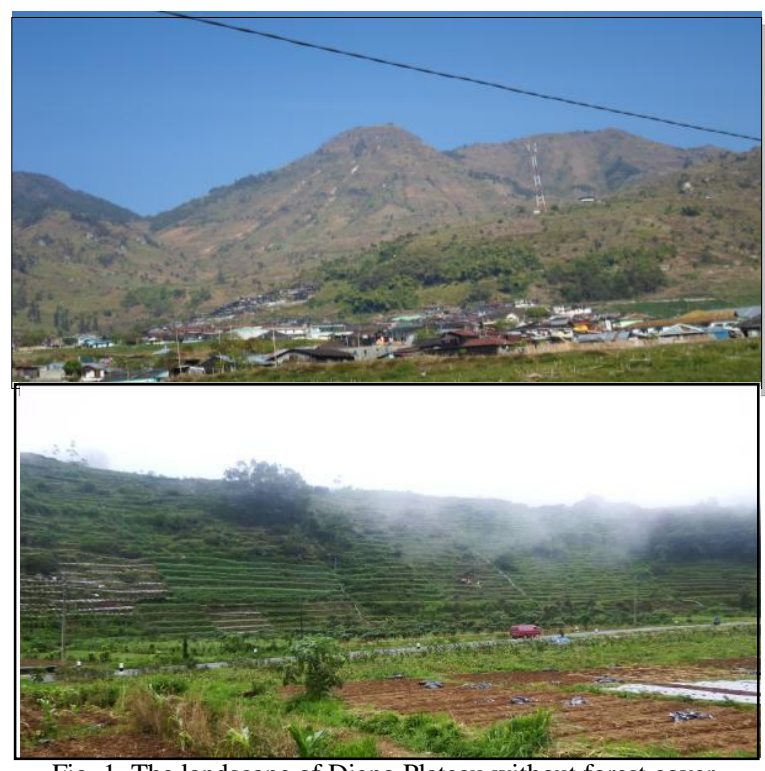

Fig. 1. The landscape of Dieng Plateau without forest cover.

\section{METHOD AND MATERIALS}

This research was conducted in Dieng Plateau, located in the Regency of Wonosobo, Jawa Tengah Province. The duration of the research was around 2 months, during September and October 2014. Data collection covered primary and secondary data. The primary data consisted of 
field survey, observation, and interview data from 15 farmers and people who settled in Dieng Plateau. The secondary data consisted of literature studies about quality and land characteristics of Dieng Plateau, also several statistical data from Indonesia and Wonosobo Central Bureau of Statistics. This research analysing qualitative and quantitative data both of analysis soil erosion rate, analysis environmental condition, and analysis of statistical data, based on analysis method this research include in descriptive research that explain the relation of some variables and process. In this research the phenomenon that occur was dominated by potato farming that had improved people's welfare but caused environmental degradation. Then this research also explain the strategy to reduce degradation process by using carica agroforestry that can improve both of ecology and economic sectors.

Analysis of environmental degradation was performed according to the standar method reported by Andriana ( 2007) using Population Pressure on Land formula that choosing four villages in Dieng as samples (Sikunang, Sembungan, Jojogan, and Dieng Wetan). The villages choose due to required the criteria, i.e the elevation should over 2,000 metres above sea level with average land slope round $25-40 \%$, moreover these four villages include in critically land area. Data for each variable collected using statistical data. While to explain about environmental degradation based on spatial analysis, this research showing the Image Landsat ETM + by Mulyana et al. (2008). The Map shows different land use around Dieng Plateau between 2007 and 2010 that indicated environmental degradation. Another method that used for analyse environmental degradation was performed by calculated soil erosion rate in potato farming. The erosion rate calculated by using USLE (Universal Soil Loss Equation) formula and Harmer formula to determined how dangerous erosion level in Dieng Plateau.

Whereas the analysis of carica agroforestry to improve ecological sector was performed using USLE (Universal Soil Loss Equation) formula, this method aim to compare different erosion rate between potato monoculture system and carica agroforestry system. Secondary data from literature study also had been used to proved that agroforestry can be the best solution to manage soil based on sustainability. While to analyse the economic impact, this research using interview data from some farmers that implementing agroforestry system in their farmland, then using statistical data about Carica industry prospect, and explain that Carica can be processed into several variants as reported by Pradana et al. (2012).

\section{ENVIRONMENTAL DEGRADATION}

Dieng's population density is quite high (approximately 100 inhabitants / kilometres square) and the limited of possession of the land has led to high pressure on the protected area and result in the big change of the functions of land. The research explain that the Population Pressure on Land in Dieng Plateau is very high, and can be calculated using this formula:

$$
\mathrm{PPL}=Z \times(1-\alpha) \frac{\mathrm{FPo}(1+r) t}{L}
$$

The calculation took samples in four villages in Dieng, i.e. Sikunang, Sembungan, Jojogan, and Dieng Wetan in Kejajar District, Wonosobo. The over view of four villages can be seen in Fig. 2, which is shown the satellite image. From the image interpretation, most of forest surround the villages had been cleared for potatoes farming. The forest only covered little spaces on the top of the hills.

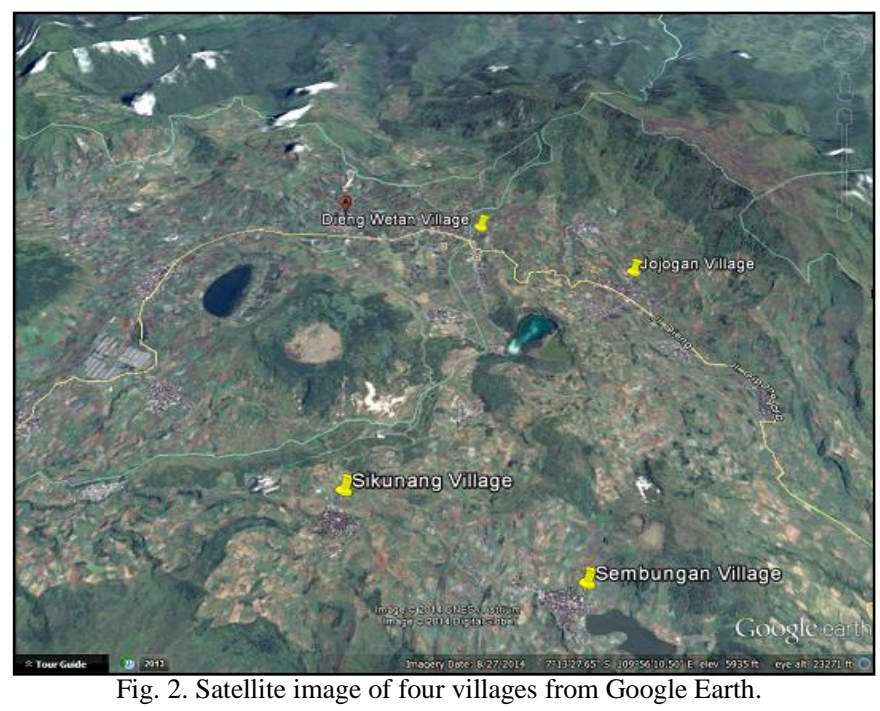

where $Z$ is equivalent with the total effective land for farmers to being able produce rice about $650 \mathrm{~kg} /$ year ( Indonesia Central Bureau of Statistics Standard ). Data for each farmer is equivalent to the value of 0.58 ha. While $\alpha$ is the income of farmers outside the agricultural sector (in \%) but because people only worked as a farmer, so the value of $\alpha$ is $0 . \mathrm{F}$ is the proportion of farmers in the population (in \%) of which in this case amounted to $33.82 \%$. Then $P$ is the population at time $t=0$ (people) and totalled 6,702 people. Whereas, $\mathrm{r}$ is the rate of growth of the population per year $(\%)$ was that the number reached $0.02 \%$ and $t$ is the time of year ranges ( 5 or 10 years). $\mathrm{L}$ is the total area of agricultural land (hectare) in four villages totalling 539.349 hectares. The result according to the formula of Population Pressure on Land is 1.24. According the theory, the value of PPL $\leq 1$ show that the capacity of land still enough to provide the population based on ecological demand (under population). Where the value of PPL is 1 it is the capacity reach it's optimum population. Whereas, the value TP $>1$ is means that the population exceed the capacity of land (over population). The value (1.24) means that there are Population Pressure on Land in Dieng.

Dieng plantation over the years only used monoculture system with potatoes as the main commodity. This resulted in a reduction in soil fertility due to specific nutrient content of the soil is absorbed by the potatoes continuously, without crop rotation. Other problem occurred due to extensification of land extending potatoes that are not accompanied by reforestation. This led to massive deforestation which in turn causes erosion. Illegal logging also has been reduced the quality and quantity of river water, so increase the potency of disaster mostly landslide. This land conversion led to severe land degradation, about 7,758 hectares of land has become critical and has high erosion rate. Potatoes are grown on thin soils, but this critical area can still be driven potato crop production due to chemical fertilizers and pesticides in large doses. Besides going to pollute the environment, the use of 
chemical fertilizers and pesticides also poison excessive potato plants so that potatoes contain a lot of chemical materials.

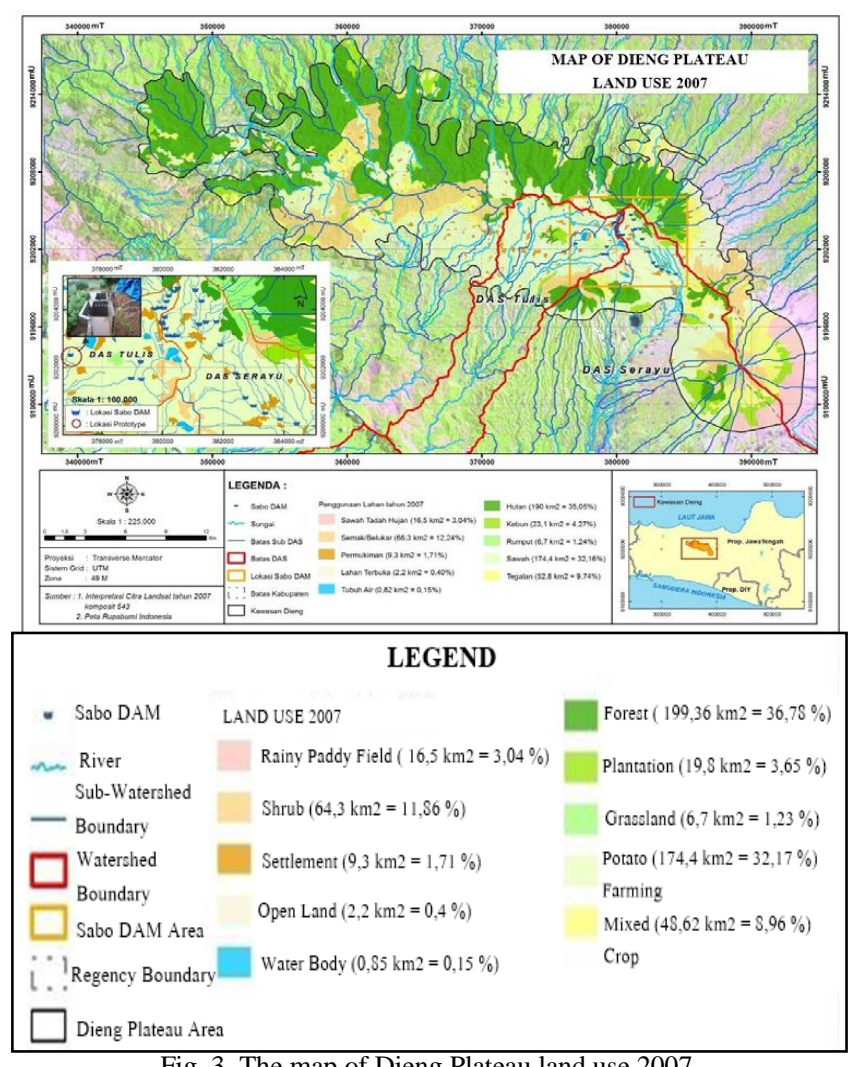

Fig. 3. The map of Dieng Plateau land use 2007.

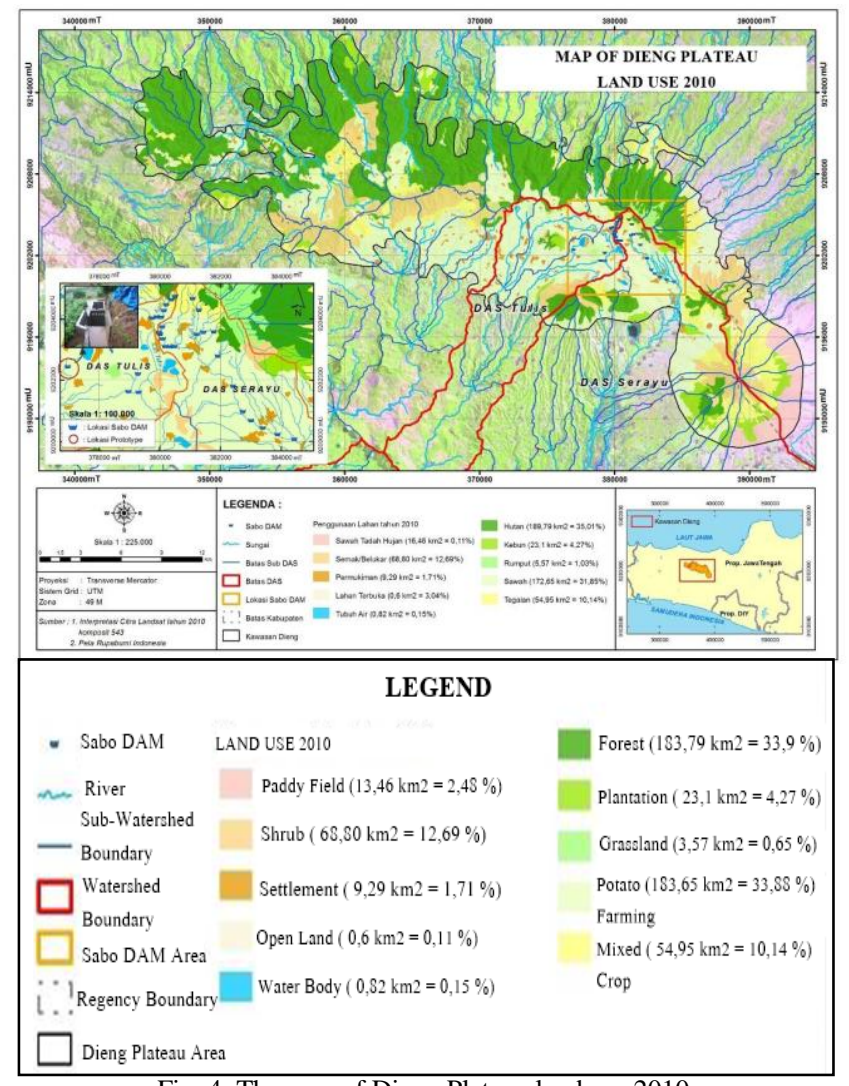

Fig. 4. The map of Dieng Plateau land use 2010.

The slope of the land in Dieng area reaches $35 \%$ to more than $45 \%$ so that the farmers Dieng use tillage systems terracing, but excessive tillage done. Even the terracing has made until reach the tops of the hills, by using contour parallel system to growth the plant (not the mountain belt), so made Dieng be prone to erosion, moreover there is no trees belt surround the farm. The erosion rate has reached 161 tons/hectare/year. Eroded soil caused a decline in land productivity, infiltration rate, and the ability of soil to retain water, causing Dieng area prone to landslides and flash floods [3]. GIS Research with Image Landsat ETM+by Mulyana et al. indicates that the conditions of use of state forest land in Dieng based is composed of forest, non-forest, nature reserve and lake / pond as can be seen in Fig. 3 and Fig. 4. Based on Image analysis, $63,22 \%$ dominated by non-forest areas in 2007 , forest only $36,78 \%$. Then, the number of forest continuously decreased, in 2010 forest only covered 33,9\% of the total area, so $66,1 \%$ dominated by non-forest areas. The density of vegetation in the area shows up rarely meeting [4]. Ideal conditions forests in Dieng ideally should be conservation forest.

Another problem associated with soil erosion and sedimentation, due to the lack of vegetation cover and the use of monoculture system as can be seen in Fig. 5. It is damaging ecosystems are some important watershed, such as Tulis and Serayu [5]. Nowadays the damage condition caused farmers face limited water resources, due to the forests clearance and wrong potatoes farming system. The results of interviews with farmers showed that their reason to planting potatoes in slope parallel system done to make rain water flowing down faster, thus avoiding the root of potatoes become rot. However, this method results in an increased rate of erosion due to the more material can be transported by surface run off.

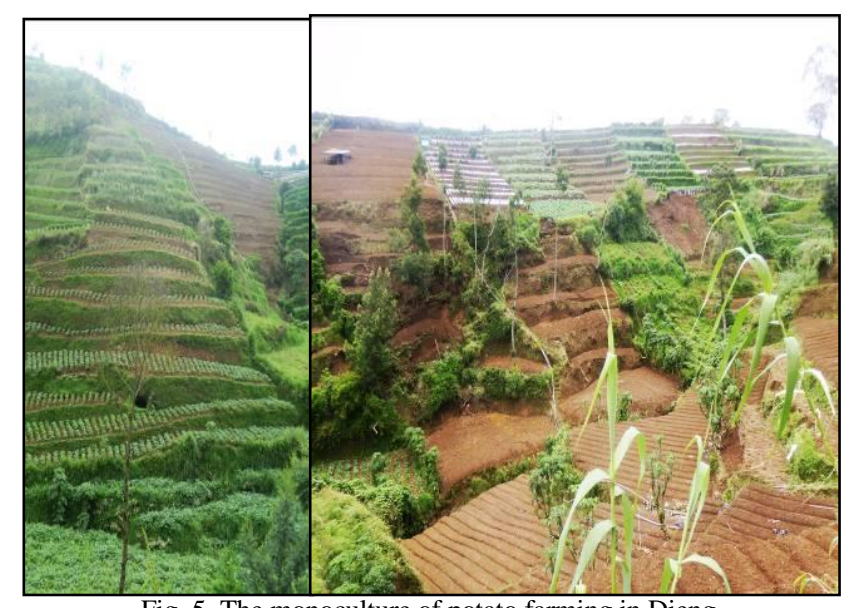

Fig. 5. The monoculture of potato farming in Dieng.

Since 1989, erosion in the Serayu watershed also led to the increase sedimentation in Sudirman dam, Banjarnegara. Siltation in this reservoir has reached $60,106 \mathrm{~m}^{3}$ or $40 \%$ of the capacity of the reservoir. The addition of the highest sediment occurred during $2000\left(7,106 \mathrm{~m}^{3}\right)$ in the event of large-scale deforestation in the Dieng plateau. This sedimentation has reduced productivity of Sudirman hydroelectric (Banjarnegara) and hydro power Garung (Wonosobo) as the Java-Bali power supplier.

In addition besides pollute the river, sedimentation also contaminated some lakes, such as Merdada, Cebong, Warna, Pengilon, and Balekambang. Sedimentation reduced the size of the lake, as well as causing silting. This has an impact on the tourism sector, given that the five lake water is a tourist destination Dieng Plateau. The damage environmental 
condition around the lake can be seen in Fig. 6, which shows the condition of Cebong lake in Sembungan Village. Dieng recovery effort is not easy because a there are multi sectoral issues that involves many aspects. Agriculture's yield contribute for $48.96 \%$ of the Gross Domestic Products of Wonosobo in 2013, potato farming has also made the standard of living of farmers especially in the Kejajar District (Dieng) increased.

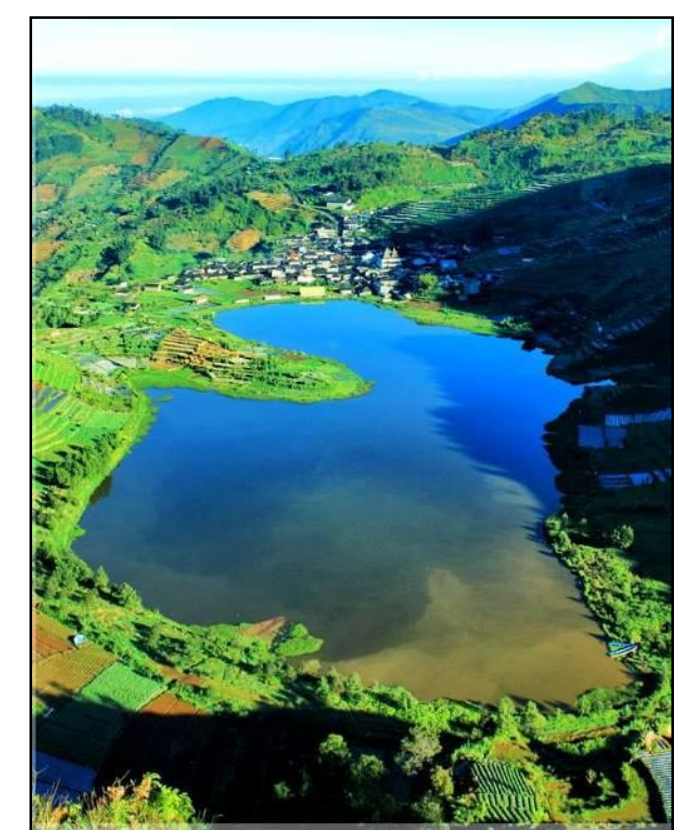

Fig. 6. Landscape around Cebong lake in Sembungan village.

\section{POTENCY OF CARICA}

Dieng's potencies are not only potatoes, but there are some endemic plants, one of them is Carica as can be seen in Fig. 7. Carica is a kind of papaya plant with small yellow fruit that comes from Latin America. Carica Dieng has a latin name Carica candamarcensis sp. In Indonesia, this plant can only flourish in Dieng. Although this plants is typical in Dieng, but in fact the cultivation is not so much, compared with potatoes that have total area about 5,013 hectares. According to data from the Department of Wonosobo Agriculture and Plantation, the harvested area for Carica plant in 2013 only 115.77 hectares with output 729 kilograms/tree/hectare.

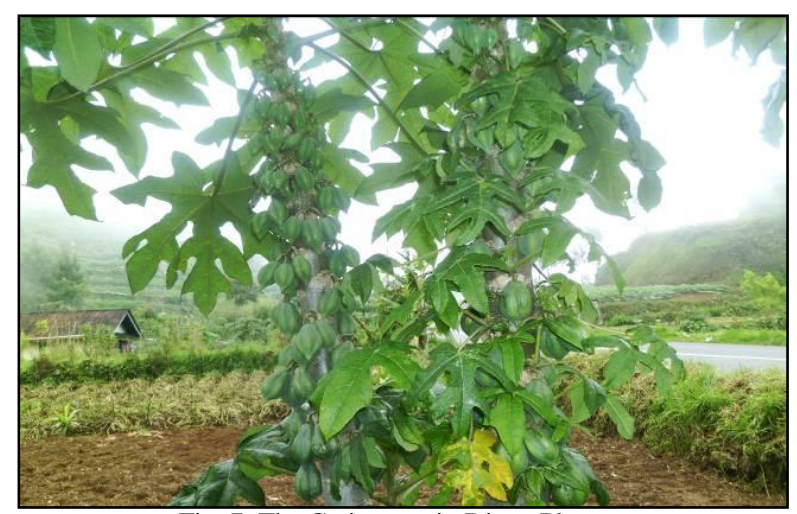

Fig. 7. The Carica tree in Dieng Plateau.

As a local potency, the development of Carica farms still underutilized by the community due to lack of knowledge and lack of public interest about the processing Carica as a superior product. Most Carica farmers only sell Carica to
Market in a raw state. Ecologically, Carica tree has strong roots than potatoes so as to reduce the rate of erosion and disaster risk. In addition, the age of the tree is longer than potatoes which is about 20 years old and do not require intensive management like potatoes. Actually, Carica can be used as a potential commodity that will benefits both ecologically and economically.

From the interview, most of the farmers (12 from $15=80 \%$ ) said that the potato crop is not so prospective again. Some farmers ( 7 from $15=46 \%$ ) in Dieng also began to realize that planting potatoes in there destroying the environment Dieng. Thus, some of them (9 from $15=60 \%$ ) began to switch plant crops other than potatoes, among others carica and other vegetable crops even if only as a byproduct plants. Conversion of this plant is expected can change the people's mindsets that desperate with economy problems. Carica problem it self is expected to be used as agricultural solution in Dieng area to increase the carrying capacity of environment with community based development.

\section{THE SCHEME AND PROSPECT OF CARICA FARMING}

Collective Carica farm has been introduced since the year 2013, where the Carica trees by some farmers had planted as cover crops around the potato fields. The existence of training by the government and academics, and also there is an increase in market demand for Carica make more enterprising farmers planting Carica. Efforts to diversify agricultural commodities with Carica and other crops such as eucalyptus has been supported by the majority of farmers Dieng. From the results of interviews with farmers in the year 2013 it is known that the farmers were satisfied with Carica commodities. Carica not require chemical fertilizers such as potatoes, moreover the harvest of Carica is very abundant The potatoes were harvested each 6 months, with 1 kilogram of potatoes valued Rp.10.000 (approximately 1.2 USD, with currency value 1 USD=Rp.12.000. While Carica can be harvested each 1 month with yields up to 20 kilograms each harvest. Carica market prices continue to rise, a recent survey (October, 2014) it is known that the price of 1 kilogram of Carica reach Rp.6.000 (approximately 0.5 US\$).

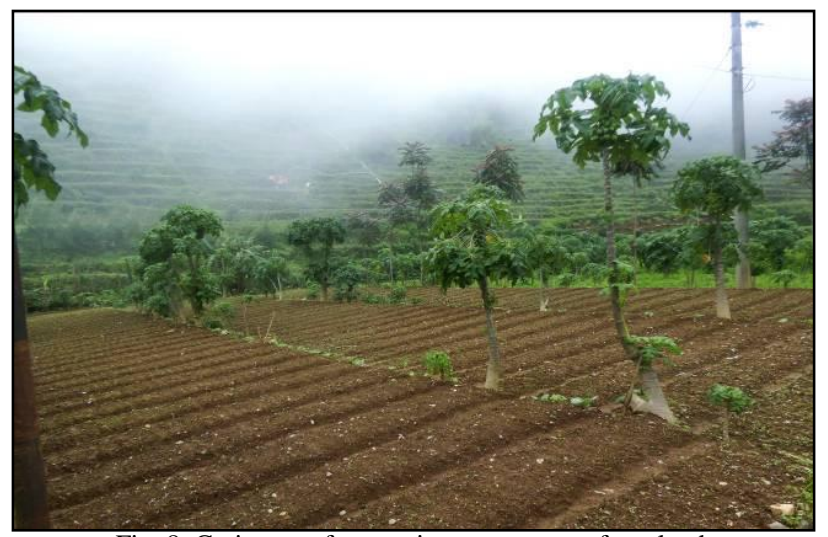

Fig. 8. Carica agroforestry in new potatoes farm land.

In an attempts to do the Dieng Recovery Program, Government of Wonosobo filed a patent of Carica as native plants from Dieng, this addressed to the Indonesian Ministry of Law and Human Rights. Next steps of the government is distributing of seedlings of fruit Carica many as 1,000 
seedlings to each village and created some cultivation training to made Carica syrup as people's business economy. The goverment also promoted agroforestry of carica around farmer's potato farm and around villages as can be seen in Fig. 8 and Fig. 9. Carica development is done by improving the quality of rural agro-industries such as through the development Carica as multi product commodity, and tourism development based on agriculture (agrotourism) to support environmental protection in accordance with the principles of ecotourism.

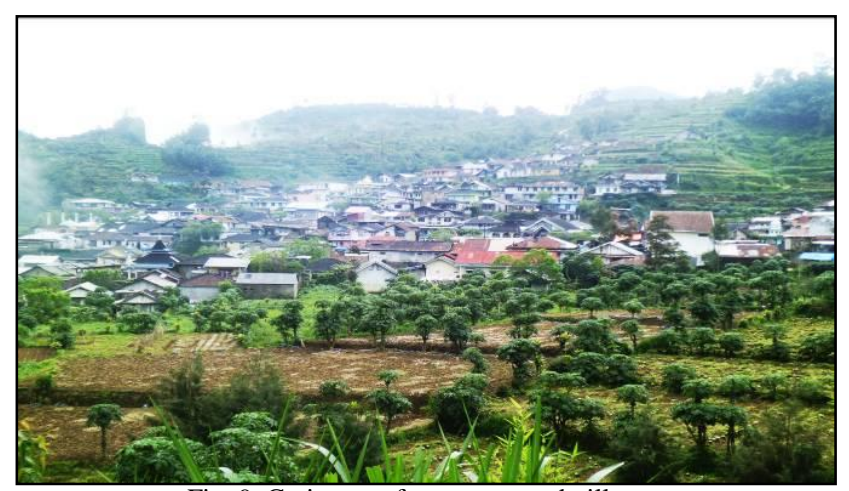

Fig. 9. Carica agroforestry around villages.

Research relates to the development of Carica's variants in 2012 by Pradana et $\mathrm{al}$. proved that Carica can be processed into a variety of variants. Some processed into various products like food, such as ; syrup, candy, ice cream, jam, and lunkhead. In addition, the distillate of Carica can be used as an ingredient for perfumes and the seeds can be used as medicines for cancer, as well as pointilis artwork [6]. With the promotion and further training to develop Carica business is expected to increase the interest of farmers to plant Carica in their garden, and are willing to undertake reforestation in protected areas. It also will support the Dieng recovery program to restore the environment, reduce the rate of erosion due to surface run off, as well as reducing environmental stress due to potatoes farming.

\section{AGROFORESTRY SYSTEM}

Attempt to restore land condition can be done with soil conservation techniques, both of vegetative and mechanical technique. Soil conservation that are more acceptable to farmer is a vegetative techniques, it's can be done with agroforestry systems. Agroforestry can be used as one of the solutions to revitalize Dieng, besides using reforestation scheme. Agroforestry is a form of resource management that combines forest management activities by planting trees or woody plants, or short- term commodities, such as agricultural crops. In this case, agroforestry apply the concept of natural balance between the management of land for cultivation and as a protected area [7].

Agroforestry practices and systems can be classified according to their components and their temporal and spatial arrangement [8]. World Agroforestry Forum had classified some various types of agroforestry as can be seen in Fig. 10. The division into rotational, spatial-mixed and spatial-zoned practices is related to the types and degrees of interaction between tree and crop components, and forms a basis for research. Management options for restoring or maintaining soil fertility may be constrained by:

- Type of land: The option is only applicable on land of certain kinds

- Extent of land: The option requires land additional to that under cultivation

- Supply problems: Availability or cost of inputs.

Most non-agroforestry methods suffer from one or more of these constraints. The various agroforestry practices are applicable to a wide range of environmental conditions and do not require inputs that are in short supply or costly. The land requirements of the tree component may be compensated either by higher crop yields or by the value of products from the tree. Thus, agroforestry is widely applicable as a practical management option. One of its greatest potentials is to help solve land-use problems in areas of sloping land [9]. Agroforestry focuses on a variety of trees planted in agricultural work and in the rural landscape. Among these are fertilizer trees for land regeneration, soil health and food security; fruit trees for nutrition; fodder trees that improve smallholder livestock production; timber and fuel wood trees for shelter and energy; and medicinal trees to combat disease [10].

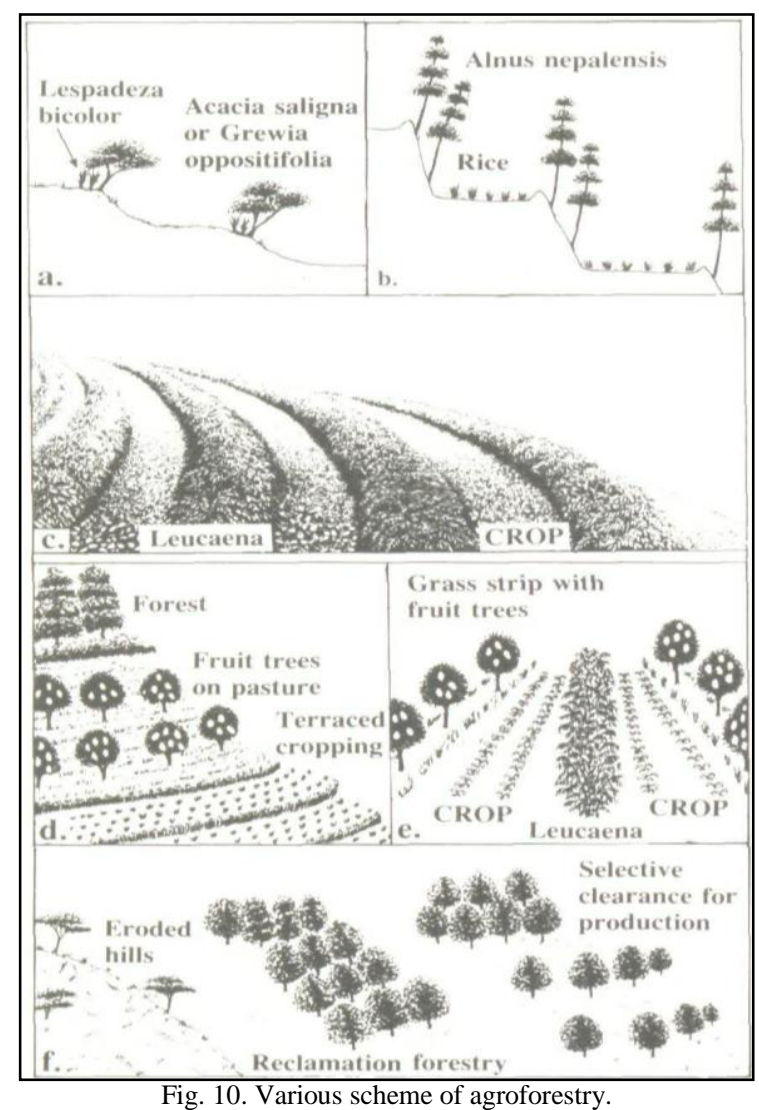

Potato plantation land management with the concept of agroforestry must be conducted in accordance with zoning scheme. The area that really should be protected such as area with slope more than $40 \%$ should not be used as an agroforestry area but is intended only for the protected forest. Meanwhile, the area below it can be managed by the principle of agroforestry that combining crops of potatoes with trees around farmland. This concept is very efficient to produce profitable plantation ecologically and economically.

Ecologically, the concept of agroforestry can protect the soil from erosion by rain water. The calculation of the rate of 
erosion $(A)$ in potato farming Dieng can use the formula of USLE ( Universal Soil Loss Equation ):

$$
\mathrm{A}=\mathrm{R} \times \mathrm{K} \times \mathrm{LS} \times \mathrm{CP}
$$

where $R$ is Precipitation Erosivity (mean Dieng precipitation rate $=3,340 \mathrm{~mm} /$ year) equal with $2,842.284$. While $K$ is Soil Erosivity of Dieng which has Andosol soil type that dominated by clay-sand particles, it is equal with 0.3 . Then, LS is slope gradien that have a score between $25-40 \%$, it equal with 6.8. Whereas $\mathrm{CP}$ is factors of landuse and land cover, which is in Dieng the CP value equal with 0.08 due to Dieng's landscape using terrace system with potato farm. The calculation shows that $A$ value is 463.86 tonnes/hectares/year [9].

Furthermore the using of Hammer's formula can determine the dangerous level of erosion (TBE):

$$
\mathrm{TBE}=\frac{\mathrm{A}}{\mathrm{TSL}}
$$

The calculation shows that the value of TBE is 48.32 tonnes/hectares/year. Where TSL is allowed erosion rate (9.6 tonnes/hectares/year). The level of TBE in Dieng according to Hammer's classification include in very dangerous level. The implementation of agroforestry in most crop land in the Dieng plateau proven to reduce the rate of soil erosion. By using the formula USLE and Hammer can be seen that the rate of erosion carica agroforestry lower than potatoes farm. The calculation is performed by matching the parameters, namely $R, K$, and LS. While the value of $\mathrm{CP}$ is 0.02 due to the land covered by inter cropping terraced plantation are. So that the erosion rate $(A)$ is 115.96 tonnes / hectares / year and the level of TBE is 12.07 tonnes / hectares / year.

As a system in the form of spatial arrangement or sequence of agricultural crops and trees, agroforestry also supports community economic development. Planting Carica help improving the local economy beyond the potato sector. The principle of agroforestry help people get more benefit, with can sell other products. Agroforestry also help maintain soil fertility plantations, thereby decreasing the use of agrochemicals so that will lower the cost of production. It also prevents the loss of capital if one day occur crop failure in potato farm, because still any other commodities that can be marketed.

Planting trees around the open potato plantations can reduce the rate of erosion, because the tree stands will minimize the energy of rainwater on the land surface, slowing the rate of surface run-off and increase the potential for infiltration and interception. In addition, the tree stands can act as a wind breaker, to prevent erosion by wind and prevent the destruction of plantation land in heavy rain or in strong winds condition. Agroforestry also support the attempts of soil conservation. Implementation of agroforestry that also acts as the principle of inter cropping, able to regulate the content of soil nutrients and increase fertility by preventing further erosion and increase soil biotic elements. Agroforestry also supports the provision of ecosystem as a biodiversity conservation efforts for a particular organism that is currently habitat has been lost due to the expansion of potato plantation [11]. The benefits of agroforestry can be seen in Fig. 11 that explain about ten hypothesis for soil agroforestry.

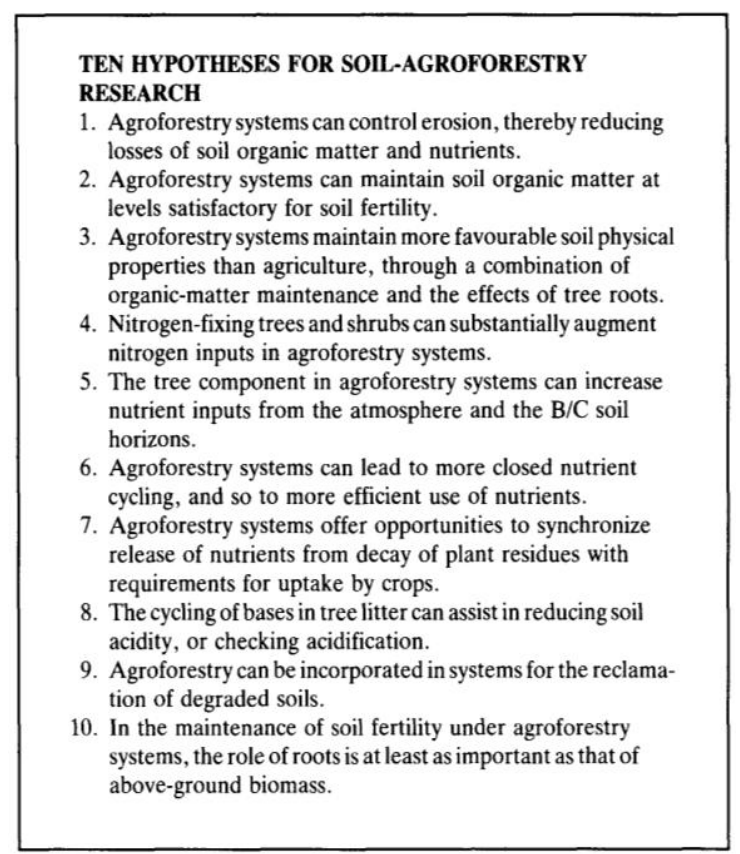

Fig. 11. Ten hypothesis for soil agroforestry research.

\section{CONCLUSION}

Potato farming activities in Ding performed by disregarding environmental conservation, this is evidenced by the use of chemical fertilizers and pesticides excessive, illegal logging of protected forests and planting potatoes in wrong technique. Land degradation has reduced the carrying capacity of the environment. Population growth and limited agricultural land, making PPL ( Population Pressure on Land) becomes high with a value of 1.24. Carica as a Dieng potency can be used as a strategy to support the conservation program to revitalize and recover the Dieng's condition. As an attempt to restore Dieng condition, the plantation of Carica must be in innovation mostly in its farming technique and its product variation, so it will increase the interest of farmers to plant Carica.

One of the most best innovation is using agroforestry scheme. Agroforestry refers to land-use systems in which trees or shrubs are grown in association with crops (agricultural crops or pastures), in a spatial arrangement or a rotation, and in which there are both ecological and economic interactions between the trees and other components of the system. In this scheme, the potatoes farm will mixed by Carica trees on the same land. The using of agroforestry will not only improve ecological condition but also improve economic and social condition. The using of Carica trees reduce the rate of erosion from 463.86 tonnes/hectares/year to be 115.96 tonnes / hectares / year (estimation data by using USLE formula). Agriculture scheme expected to change the mindset of the people to harness the potential of the area based on sustainable development to support Dieng recovery that have an attempt to reduce the environmental crisis as a result of potato farming.

\section{REFERENCES}

[1] B. L. H. K. Wonosobo, Data Status Lingkungan Hidup Daerah Wonosobo, Wonosobo, Indonesia, BLH Press, ch. 1, 2013, pp. 5-7. 
[2] B. Soelarso, Budidaya Kentang, Yogyakarta, Indonesia, Jeanisus, ch. 2, 1997, pp. 34-35.

[3] I. S. Banuwa, Erosi, Jakarta: Kencana, 2013, ch. 1, pp. 3-5.

[4] A. R. Mulyana et al., Evaluation of Land Utilization and Mud Flow Controlling in Dieng Plateau, Yogyakarta, Indonesia: Pusat Litbang Sumberdaya Air, 2008, pp. 5-7.

[5] R. Rukmana, Teknik Pengelolaan Lahan Berbukit dan Kritis, Yogyakarta, Indonesia: Konisius, 1995, ch. 4, pp. 89-92.

[6] A. Pradana, O. Lesagia, and R. S. Martyna, Pengembangan Varian Produk Carica (Carica Candamercensis) Sebagai Upaya Penyelamatan Lahan Kritis Dataran Tinggi Dieng Kabupaten Wonosobo, Wonosobo, Indonesia: SMA Muhammadiyah Wonosobo, 2012, pp. 15-19.

[7] J. Dove, Geography fo A2, UK: Cambridge University Press, ch. 2, pp. 45-47.

[8] L. Reijntjes, B. Haverkort, and A. W. Bayer, Future Agricultural System, Yoyakarta, Indonesia: Kanisius, ch. 4, pp. 78-82, 2011.

[9] R. Andriana, "Evaluation of conservation area in Dieng Plateau," M.Si. thesis, Dept. Environmental Studies, Diponegoro University, Semarang, Indonesia, 2007.

[10] World Agroforestry Centre. (November 2014). Agroforestry for control of soil erosion. World Agroforestry. [Online]. ch. 6. Available: http://www. worldagroforestry. org/units/library/books

[11] World Agroforestry Centre. (November 2014). Agroforestry for soil conservation. World Agroforestry. [Online]. ch. 16. Available: http://www. worldagroforestry. org/units/library/books

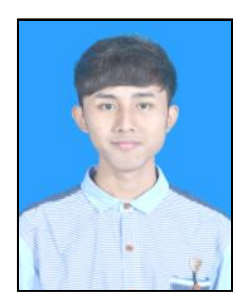

Aditya Pradana was born in Wonosobo, Indonesia on March 15, 1997. He finished his school study in SMA Muhammadiyah Wonosobo in 2014, and now he is an undergraduate student in Faculty of Geography, Gadjah Mada University, Indonesia. His study major is environmental geography which concern in physical and human geography.

His current research interests include environmental and geomorphology, disaster management, and urban planning. He is a fellow of the Environmental Geography Student Association. In September 2014 he published scientific articles about integrated water planning in Serayu watershed, Central Java and got research award from the Indonesia Ministry of Forest. He has other researches such as making some variants of Carica products in 2012 and soluting for transportation problems in Yogyakarta in 2014.

He was one of the Indonesia delegations for International Geography Olympiad in two years. In 2013 he got bronze medal and second award for poster presentation about traditional sanitation based on local wisdom in Indonesia. In 2014 he got silver medal and third award for poster presentation about waste management in Bandung urban area. In national level, he got bronze medal in Earth Science Olympiad that held by the Ministry of Education and got gold medal in National Geography Olympiad that held by Gadjah Mada University.

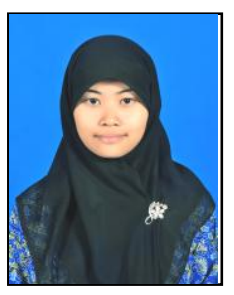

Futuha Helen Sara was born in Tuban, Indonesia, on November 23, 1996. She finished her school study in SMAN 1 Bojonegoro in 2014, and now she is an undergraduate student in Faculty of Geography, Gadjah Mada University, Indonesia. Her study major is environmental geography which concern in physical and human geography.

Her current research interests include demography, environmental study, and disaster management. She is a fellow of the Environmental Geography Student Association. In 2013 she made and published some research, such as wave modelling project as a study about disaster mitigation in Indonesia coastal zone, development of agrotourism in Pandan mount as an attempt to increase economic and tourism sector in Bojonegoro regency, and the using of husk waste as an attempt to regenerate the soil aggregate.

She was a participant in national geography olympiad 2013 that held by Gadjah Mada University. She also participated in earth science olympiad 2013 that held by Indonesia Ministry of Education. She also got the second winner for geomathic engineering olympiad in 2013. More over, she got some achievement for her participation in some research activities, such as about pollution from traditional mining in Kendeng mountain and the calculation of electricity conductivity in the mouth of Progo river.

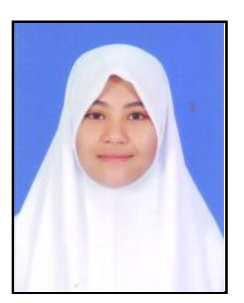

Windarti Wahdaningrum was born in Wonosobo, Indonesia, on November 27, 1995. She finished her school study in SMA Muhammadiyah Wonosobo in 2014, and now she is an undergraduate student in Faculty of Geography, Gadjah Mada University, Indonesia. Her study major is environmental geography which concern in physical and human geography.

Her current research interests include economic geography, agricultural geography, and geopolitics. She is a fellow of the Environmental Geography Student Association. In 2013 she made a research about the using of "frog jump" as a innovation in mathematics teaching method for difable students, then she also made a scientific essay about Carica and agriculture in Dieng Plateau.

In 2014 she got a gold medal in National Geography Olympiad that held by Gadjah Mada University, while in 2013 she was a participant in National Geography Olympiad 2013 that held Indonesia Ministry of Education. 